American Journal of Pharmaceutical Education 2019; 83 (2) Article 7422.

\title{
COMMENTARY
}

\section{Development of Guiding Principles for a New Era in Graduate Education}

\author{
David J. Feola, PharmD, PhD ${ }^{\mathrm{a}}$, Esther P. Black, $\mathrm{PhD}^{\mathrm{a}}$, Patrick J. McNamara, $\mathrm{PhD}^{\mathrm{a}}$, Frank Romanelli, \\ PharmD, MPH ${ }^{\mathrm{a}, \mathrm{b}}$ \\ ${ }^{a}$ University of Kentucky College of Pharmacy, Lexington, Kentucky \\ ${ }^{\mathrm{b}}$ Executive Associate Editor, American Journal of Pharmaceutical Education, Arlington, Virginia \\ Submitted November 12, 2018; accepted December 6, 2018; published March 2019.
}

\begin{abstract}
Many external drivers may be influencing a paradigm shift in graduate education. Workforce dynamics are driving a re-examination of what is instructed in graduate programs as well as how curricula are delivered. Most graduate programs have made incremental changes in their philosophical approaches, but new and more dramatic paradigms may be needed to sufficiently address the future needs of employers and students alike.
\end{abstract}

Keywords: graduate education, pharmaceutical sciences, research, future

Graduate education plays a critical role in the advancement of society and the maintenance of the global economy. The future of graduate education in the United States and beyond is at a crossroads. ${ }^{1,2}$ Current challenges have dictated in-depth examinations to determine how to optimally maintain relevance and impact. Graduate education develops critical thinkers and innovators who will be the thought leaders of tomorrow. However, some hypothesize that the gradual evolution of the delivery of graduate education is not keeping pace with the rapidly changing world of drug discovery, drug development, and the advancement of therapeutics. ${ }^{3}$ Several aspects of the current model of graduate education are antiquated, and philosophical changes are needed to best serve our students as they prepare to enter the workforce and thereby adequately meet the needs of today's society.

The financial sustainability of current graduate training paradigms is in question. Historically, graduate education in pharmaceutical sciences has been financially supported by a variety of mechanisms (eg, state allocation, public and private grant support resources, teaching assistantships, and undergraduate/professional program tuition revenue), all of which are under increasing pressure. State legislatures have greatly reduced their support of higher education, and, as a result, universities have adjusted by increasing tuition which in turn shifts the cost of graduate education to undergraduate and professional students. Complicating an already precarious situation, there has been a shift at the National Institutes of Health

Corresponding Author: David J. Feola, University of Kentucky College of Pharmacy, 789 S. Limestone St., Rm. 231, Lexington, KY 40536, Tel: 859-323-8751, E-mail: david. feola@uky.edu to train a larger proportion of students through training grants, thereby decreasing the number supported through major funding mechanisms as research assistants which have traditionally supported graduate students. ${ }^{4}$ In the face of financial challenges, there exist inefficiencies, including low completion rates and prolonged duration of time to degree completion. ${ }^{5,6}$ Importantly, mounting student debt, the length of time to degree, and uncertainty of job opportunities (academic and industry) in a rapidly changing environment have led to a waning number of domestic students expressing interest in graduate education. Lastly, increasing global competition for top students, primarily by institutions in Europe and China, have placed a strain on programs striving to attract top-level talent. ${ }^{7}$

Many graduate programs have undergone minor changes and modifications, primarily in a reactionary fashion, regarding philosophy, the way students are recruited, the means by which programs support their mentors, the means by which content is constructed and delivered, and how trainees are assessed. These changes have not fundamentally shifted the traditional and entrenched paradigm associated with the decades-old model. Graduate education has been locked into a period of incremental change and quick fixes; but, similar to professional education, the time has come for disruptive transformation. Educators charged with instructing and overseeing graduate programs may be able to garner ideas and roadmaps from recent evolutions in Doctor of Pharmacy (PharmD) degree programs across the US.

This raises the question as to how a program, institution, or the Academy goes about forging change. At the University of Kentucky College of Pharmacy, we recently began a commitment to re-envisioning graduate education. Our goal is to make large, substantive changes in aspects of our program to ensure that we are optimally 


\section{American Journal of Pharmaceutical Education 2019; 83 (2) Article 7422.}

serving our students, the job market, and society. The American Association of Colleges of Pharmacy (AACP) Research and Graduate Affairs committee has weighed in on this topic and published reports suggesting several changes that are needed, including the adoption of a list of core competencies. ${ }^{3,8-11}$ We believe that the Academy should also formulate a set of guiding principles on which to build lasting change. This is especially important given that, unlike with professional education, there are no accreditation standards or specific accrediting body that serves as a benchmark and impetus to drive change.

These core principles should be rooted in a holistic, student-centric model that puts the needs of trainees at the forefront. These principles should also establish a foundation for curricular goals that ensure optimal education not only in depth of the scientific field, but also in breadth of knowledge across pharmaceutical sciences disciplines. Students should also be trained in a manner that promotes the abilities to effectively work as parts of diversified teams. Additionally, principles can serve to define goals of recruitment, the importance of diversity, and the significance of effective mentorship. Shifting forces within the pharmaceutical industry and academia have transformed workplaces and research environments into models built around team-based approaches to solving problems. This, in turn, will place a premium on power skills including teamwork, communication, entrepreneurship, and innovation. We must foster these skills so that trainees become professionally adaptable and agile while simultaneously becoming experts in their field of research. Due to current funding trends, tension has developed between the use of graduate students to further the research agenda of individual faculty and the optimal training of students. While there exists an interface between the function of trainees and other missions of the college (research, teaching, and community engagement), these principles must be designed so that the education of the graduate student is paramount.

Most agree that holistic, student-centric training which includes career-based skills is important, but the path to this goal remains unclear. The impact that such a conversion would have on our ability to instruct scientific depth and rigor is uncertain. Educators must be purposeful in programmatic decision-making so as to not compromise training in any area while simultaneously shortening the overall duration of time it takes to complete a $\mathrm{PhD}$ program. Development of and adherence to a list of basic principles that can guide decision-making could provide lasting and institutionalized change.

Training graduate students is a core mission of the Academy, and to do so in a rapidly changing world will require radical change. We must equip students to succeed in an evolving landscape so that innovative and en- trepreneurial aspects of drug development and utilization continue to advance. The time to make these disruptive changes is now, and a firm foundation is required in order to make lasting transformations that will impact our graduates and the field of pharmaceutical sciences for years to come.

Note: The UK Pharmaceutical Science Graduate Program Guiding Principles document can be found at pharmacy.uky.edu/phd-pharmaceutical-sciences.

\section{REFERENCES}

1. Wendler W, Bridgeman B, Cline F, et al. The path forward: the future of graduate education in the United States. Educational Testing Service, Princeton, NJ. 2010.

2. Leshner AI. Rethinking graduate education. Science. July 24, 2015;349(6246):349.

3. Wu-Pong S, Gobburu J, O'Barr S, et al. AACP Graduate Education Special Interest Group. The future of the pharmaceutical sciences and graduate education: recommendations from the AACP graduate education special interest group. Am J Pharm Educ. May 13, 2013;77(4):S2.

4. Tilghman S, Rockey S, Degen S, et al. National Institutes of Health. Biomedical research workforce working group report: a working group of the advisory committee to the director. https://acd. od.nih.gov/documents/reports/Biomedical_research_wgreport.pdf. Published June 14, 2012. Accessed November 6, 2018.

5. National Science Foundation. National Center for Science and Engineering Statistics Directorate for Social, Behavioral, and Economic Sciences. 2016 doctoral recipients from U.S. universities. https://wayback.archive-it.org/5902/20180503131148/https://www. nsf.gov/statistics/2018/nsf18304/static/report/nsf18304-report.pdf. March 2018. Accessed November 7, 2018.

6. Sowell R. Council of Graduate Schools. Ph.D. completion and attrition: analysis of baseline program data from the Ph.D.

Completion Project. https://cgsnet.org/sites/default/files/

phd_completion_attrition_baseline_program_data.pdf. Accessed November 7, 2018.

7. Okahana H, Zhou E. Council of Graduate Schools. International graduate applications and enrollment: Fall 2017. https://cgsnet.org/ ckfinder/userfiles/files/Intl_Survey_Report_Fall2017.pdf. Published 2018. Accessed November 7, 2018.

8. Brueggemeier RW, Clark AM, Das SK, et al. Research and Graduate Affairs Committee. The path forward: the future of graduate education in the pharmaceutical sciences: the report of the 2010-2011 Research and Graduate Affairs Committee. Am J Pharm Educ. December 2011;75(10):S13.

9. Poloyac SM, Empey KM, Rohan LC, et al. Core competencies for research training in the clinical pharmaceutical sciences. Am J Pharm Educ. March 2011;75(2):27.

10. Poloyac SM, Block KF, Cavanaugh JE, et al. Research and Graduate Affairs Committee. Competency, programming, and emerging innovation in graduate education within schools of pharmacy: the report of the 2016-2017 research and graduate affairs committee. Am J Pharm Educ. October 2017;81(8):S11.

11. Poloyac SM, Cavanaugh JE, Hagemeier NE, et al. Research and Graduate Affairs Committee. Breaking down barriers to pharmacy graduate education: The report of the 2017-2018 research and graduate affairs committee. Am J Pharm Educ. September 2018; 82(7):7147. 